\title{
A Comparative Study of Enhanced Crude Oil Degradation in Three Tropical Soils using Pig and Goat Manures as Organic Amendments
}

\author{
O. A. Ojo-Omoniyi ${ }^{1 *}$, N. Dike-Ekeh ${ }^{1}$ and O. M. Owoeye ${ }^{2}$ \\ ${ }^{1}$ Department of Microbiology, Lagos State University, Ojo, P.M.B. 0001, \\ LASU Post Office, Lagos-Nigeria \\ ${ }^{2}$ Handsonlabs Software Academy, Lagos, Nigeria \\ *Corresponding author
}

\section{Ke y w o r d s \\ Biodegradation, Bio-recovery, Organic amendments, Petroleum Hydrocarbons, Pollution}

\section{Article Info}

Accepted: 20 July 2020 Available Online: 10 August 2020

\section{A B S T R A C T}

The bio-recovery of three different oil-polluted tropical soils - RS (oil-polluted soil sample from River state), LS (soil sample from NNPC depot, Lagos) and POS (oil-polluted soil sample from Oriade L.G.A., Lagos) by manure amendment was studied for eight weeks. The rates of crude oil biodegradation after manure application as quantified by Gas chromatographic analysis of residual total petroleum hydrocarbon (TPH) showed the same trend of decrease in the total petroleum hydrocarbons in both the LS and RS series. The TPH for the LSC (non-oil polluted LS soil sample as Control) series at weeks 4 and 8 were $1893.42 \pm 26.16 \mathrm{mg} / \mathrm{kg}$ and $1080.86 \pm 14.33 \mathrm{mg} / \mathrm{kg}$, this was significantly different from that of LSpg (pig manure-amended soil) which for the same weeks which were $1107.19 \pm 18.41,258.56 \pm 4.16 \mathrm{mg} / \mathrm{kg}$ TPH respectively and from that of LSgt (goat manureamended soil sample) which were $1355.15 \pm 7.45,491.24 \pm 20.82 \mathrm{mg} / \mathrm{kg}$ TPH respectively. The results show that pig manure was a better organic amendment than goat manure in the LS series soil but at the long run not better than goat manure in the RS and POS soils. Microbiological counts showed a peak at week 6 with HUF (hydrocarbon - utilizing fungi) $\left(34 \times 10^{3} \mathrm{cfu} / \mathrm{g}\right)$ for LSC; a peak at week 2 with HUB (hydrocarbon-utilizing bacteria) $\left(252 \times 10^{5} \mathrm{cfu} / \mathrm{g}\right)$ for LSpg and a peak at week 6 for LSgt with HUB $\left(91 \times 10^{5} \mathrm{cfu} / \mathrm{g}\right)$.Also, microbial counts revealed a peak in week 2 with HUB $\left(206 \times 10^{5} \mathrm{cfu} / \mathrm{g}\right.$ ) for POSC; a peak at week 8 for POSpg (oil polluted + pig manure amended Oriade soil sample) with HUB $\left(197 \times 10^{5} \mathrm{cfu} / \mathrm{g}\right)$ and a peak at week 8 for POSgt with HUB $\left(138 \times 10^{5} \mathrm{cfu} / \mathrm{g}\right)$. Microbial counts also revealed peaks at week $4\left(97 \times 10^{5} \mathrm{cfu} / \mathrm{g}\right), 64 \times 10^{5} \mathrm{cfu} / \mathrm{g}$ and $119 \times 10^{5} \mathrm{cfu} / \mathrm{g}$ for RSC (River state control soil sample), RSpg and RSgt samples respectively all with HUB. In terms of soil properties, in RS soils, pig manure added more ammonium, total organic matter, nitrate, phosphorus and potassium than goat manure; in POS soils, pig manure lowered $\mathrm{pH}$, $\mathrm{NH}_{4}{ }^{+}$,Phosphorus more than goat manure; in LS soils, goat manure added more total organic matter, sodium and potassium while pig manure added more $\mathrm{NH}_{4}{ }^{+}$, nitrate and phosphorus.

\section{Introduction}

Biodegradation of organic waste is becoming an increasingly important method of waste treatment (Atlas, 1981). The advantages of this option include its being environmentfriendly, cheap source of nutrient and its simplicity. Although, crude oil contamination has some adverse effects on crops and other vegetation. Bioremediation and phytoremediation of crude oil contaminated soil is the most promising and environmentfriendly for effective clean-up of crude oil contaminated soil (Ezeji et al., 2007). Doran 
and Parkin (1994) reported that soil quality is defined as the capacity of the soil to function within ecosystem boundaries, sustaining plant and animal health. Soil as a key component of natural ecosystems upon which environmental sustainability largely depends, therefore any pollution of the soil will undoubtedly impact the ecosystem and agricultural activities.

Crude oil pollution of soil provides an excess carbon that might be unavailable for microbial utilization, induces a limitation on soil Nitrogen and Phosphorus which may result in virtual eradication of some of the primary food chain components which in turn have major consequences on predator and consumer species (Doran and Parkin, 1994; Ezejiet al., 2005; Onuh et al., 2008). Crude oil spillages into soils also lead to high accumulation of Aluminium and Manganese ions which are toxic to plant growth. Thus, soil fertility is compromised. It is also remarkable that even at low parts per billion (ppb) concentrations, oil spillages into sub soils are destructive, creating anoxic conditions in the rhizosphere which is unfavourable to most heterotrophic soil bacteria (Baker and Herson, 1994; Atlas, 1981). However, the presence of crude oil in the environment creates a niche for specially adapted indigenous petroleum-degrading microorganisms well represented in the soil and water environments. These organisms include bacteria of the genera; Arthrobacter, Pseudomonas, Acinetobacter, Bacillus etc., while fungi such as Candida, Rhodotorula, Mortierella, Aspergillus as well as algaeProtothecazopfi, cyanobacteria, green and red alga (Ijah et al., 2008; Ezeji et al., 2005).

However, since the discovery of petroleum in large volume, pollution of the environment occurred simultaneously, bioremediation and recovery approaches to remedying polluted environments became necessary. All the approaches to recovery are based on physical, chemical and biological means. However, studies have shown that the biological approaches are the technologies of choice (Adedokun and Ataga, 2007). Since oil degradation is not limited by electron donor, that is, hydrocarbons but by supply of nutrients or oxidans (electron acceptors), to combat the plethora of environmental pollution in present day society, efficient and environmentally safe organic waste treatment technologies are needed by oil-producing countries. In consequence, enhanced crude oil degradation by soil microbiota in the presence of poultry manure in Nigerian polluted soils has been reported (Ibekwe et al., 2006; Amadi and Uebari, 1992). Amadi et al., (1993), Obire and Akinde (2006) reported that nutrient supplementation of oil-polluted soil with poultry droppings as organic nutrient source in particular is beneficial for maize growth and it also enhances both biodegradation of oil and soil recovery. Nwogu et al., (2015) investigated bio-stimulant energies of Capra aegarushircus for processing of crude oil polluted soil under certain tropical environment. Their findings revealed that $C$. A. hircus manure is an excellent bio-stimulant that enhances the performance of native hydrocarbonclastic bacteria respectively. Owabor and Yusuf (2010), Agarry et al., (2013) both evaluated the blend of poultry, piggery, goat manures as well as chemical fertilizers (kerosene, diesel and gasoline) as bio-stimulant for over three weeks of processing. The results suggested that farm feed manures displayed higher levels of degradation and hydrocarbon reductions as well as being environment- friendly. Furthermore, diverse organic fertilizers like wood ash, pig, goat manure, oil palm kernels used as amendments were observed to provide better soil nutrients compared with those of nitrogenous manures (Moyin-Jesu, 2019). Meanwhile, Ukpaka et al., (2020) reported the efficacy of Total Petroleum Hydrocarbon (TPH) mineralisation in loamy 
soil enriched (within 90 days) with water which suggested promising result compared to other soil enrichment processes. Finally, Verma et al., (2020) reported bio-gas as a good source of renewable energy and sustainable agriculture for rural areas in India using cattle dung and related wastes as recyclable sources of soil nutrients.

Although, there have been reports of laboratory investigations on the use of organic nutrients such as cow dung and poultry droppings in bioremediation of oil - polluted sites (Amadi and UeBari, 1992), there has not been investigations into the use of other organic nutrients such as pig and goat dung as biodegradation enhancing agents in southwest Nigeria. It is therefore necessary to carry out studies on the application of pig and goat droppings in bioremediation of crude oilpolluted soils.

\section{Materials and Methods}

\section{Sample collection}

Three different soil samples were used in the research-OS, RS and LS. The first 'OS' was randomly collected from an Agricultural farmland in Oriade L.G.A Lagos (that has no recorded experience of petroleum hydrocarbon pollution), at a soil depth of 15$20 \mathrm{~cm}$, using a clean soil auger. RS, soil samples polluted on site, were collected randomly at the same depth, from an Agip flow station in Ebocha, (Rivers State) into a sterile glass bottle before being transported to the laboratory. The last sample LS which was heavily flooded with crude oil at the sampling site (NNPC depot in Lagos) was collected and stored as described above. The organic manures used were collected from a local farm in Ebocha, Rivers State. Also, the crude oil type used (Ebocha Blend) was supplied by Nigeria Agip, Ebocha Flow Station, Rivers State.

\section{Physicochemical characterisation of Soils and Manures}

Samples of soils and organic manures were weighed using Mettler PE 1600 chemical balance (Gallenkamp) and their physicochemical parameters were determined as well as their petroleum hydrocarbon profiles before the manure treatments. Soil treatments were done at the ratio of 5: 1 , that is, 5 parts of soil to 1 part of manure.

\section{Pollution of soil (code OS)}

Pollution of soil was done at the rate of $200 \mathrm{mls}$ of crude oil per $1000 \mathrm{~g}$ of soil. The polluted soil was left at room temperature for 14 days during which its physicochemical parameters were determined, its microbiological properties were determined, before the manures were applied as reported above.

\section{Evaluation of residual Total Petroleum Hydrocarbon (TPH)}

Residual petroleum was quantified using gas chromatographic analysis. Residual total petroleum was extracted once as follows: $10 \mathrm{~g}$ of polluted soil was extracted with $10 \mathrm{ml}$ of Dichloromethane. After the solvent vented off, the residual TPH was dissolved in acetone and concentrated to $1 \mathrm{ml}$. TPH concentrations in the acetone were determined using the Hewlett Packard 5890 Series gas chromatograph On- Column Injector type (column OV-101, thickness and width-80/100 mesh, stationary phase WHP 5\%) equipped with Flame Ionization Detector (FID). The injector and detector temperatures were maintained at $200^{\circ} \mathrm{C}$ and $260^{\circ} \mathrm{C}$ respectively. The column temperature was programmed to rise to $230^{\circ} \mathrm{C}$. The $\mathrm{GC}$ was programmed at an initial temperature of $70^{\circ} \mathrm{C}$, this was held for $2 \mathrm{~min}$, then ramped at $10^{\circ} \mathrm{C} / \mathrm{min}$ to $230^{\circ} \mathrm{C}$ and held for 10mins (Adebusoye et al., 2007). 


\section{Isolation of petroleum utilizing bacteria and fungi}

The mineral medium described by Kastner $e t$ al., (1994) was used. The medium contains per litre $\mathrm{Na}_{2} \mathrm{HPO}_{4}, 2.13 \mathrm{~g} ; \mathrm{KH}_{2} \mathrm{PO}_{4}, 1.30 \mathrm{~g}$; $\mathrm{NH}_{4} \mathrm{Cl}, 0.50 \mathrm{~g}, \mathrm{MgSO}_{4} .7 \mathrm{H}_{2} \mathrm{O}, 0.20 \mathrm{~g}$; Agaragar, $10.0 \mathrm{~g}$. The $\mathrm{pH}$ of the medium for bacteria was adjusted to 7.2 and fortified with Nystatin and Nalidixic acid at 50ug/l to suppress fungal growth. The medium for fungi was fortified with $0.05 \mathrm{~g}$ of Yeast extract to encourage fungal growth and with $0.5 \mathrm{ml}$ of streptomycin to suppress bacterial growth. Trace elements solution ( $1 \mathrm{ml} /$ litre) described by Bauchop and Elsden (1960) was sterilized separately and added aseptically to the medium. Contaminated and uncontaminated soil samples $(1.0 \mathrm{~g})$ were serially diluted in sterile distilled water while $0.2 \mathrm{ml}$ of this serially-diluted aliquots were inoculated (with a sterile Hockey stick)on Minimal Salt Agar (MSA) plates to which crude oil was fed using crude oil-soaked sterile filter paper in vapour - phase transfer technique. These were then incubated at room temperature for 4 and 6 days for bacterial and fungal isolates respectively. Several of the colonies that appeared were further purified by subculturing on Nutrient Agar (NA), Sabouraud Dextrose Agar (SDA) plates to which crude oil was introduced by the same technique and Luria Bertani (LB) plates. The ability to degrade crude oil was confirmed by inoculating NA grown pure cultures (20h) into fresh MSA plates supplemented with crude oil. The purified isolates were then maintained on LB agar slants for further identification (Raymond et al., 1976).

\section{Microbial total count}

Aseptically $1 \mathrm{ml}$ of the serially diluted samples were inoculated by pour-plate method on solid SDA plates and NA plates for the enumeration of total saprophytic fungi and total heterotrophic bacterial counts respectively. The inoculated plates were incubated at room temperature for 72 and 48 hours respectively. Colonies which appeared on the plates were counted and expressed as cfu/g of soil.

\section{Substrate Specificity}

The ability of two of the bacterial isolates to grow on crude oil was further evaluated in $20 \mathrm{ml}$ of liquid media fortified with $0.2 \mathrm{ml}$ crude oil. Incubation was at room temperature for 32days. Degradation was monitored by TVC and visual observation for turbidity. The extent of crude oil utilization was determined using GC analysis.

\section{Identification and Characterization of Isolates}

Pure cultures of bacterial isolates were identified on the basis of their colonial morphology, cellular morphology and biochemical characteristics. Pure Fungal cultures were observed while still on plates and after wet mount in lacto-phenol blue on slides under the compound microscope. The observed characteristics were recorded and compared with the established identification key of Malloch (1997).

\section{Agricultural evaluation of bioremediated soils}

In order to evaluate the extent of remedy accomplished in the soils, one type of white corn bought from two different markets in Lagos state; Okokomaiko and Iyana-Iba were planted on the bioremediated soils at a depth of $1.5 \mathrm{~cm}$, maintained at $60 \%$ of their water holding capacities and also on the control soils that were not amended with organic manures. The dates of the emergence of plumules of the maize seeds so planted, stem and leaf measurements of the grown plants 
were used in the evaluation of the soils extent of recovery for agricultural purposes.

\section{Results and Discussion}

\section{Isolation of petroleum utilizing bacteria and fungi}

Petroleum-hydrocarbon

utilizing microorganisms identified using standard and conventional methods include; Bacillus coagulans, Corynebacterium sp., Micrococcus vairians, Acinetobacter mallei, Bacillus polymyxa, Bacillus megaterium and Micrococcus roseus while the fungal isolates include; Aspergillus tamari, Aspergillus flavus, Aspergillus candidus and Penicillium viridicatum.

Enhancement of Biodegradation of Polluted soils Amended with Organic manures

The growth kinetics of hydrocarbon-utilizing bacteria and fungi (HUB and HUF) following the addition of manures as represented in Fig. 1 showed that at week 2, 4 and 6 in the LSpg soil, HUB was more at bioremediation than HUF, but by week8, HUF was slightly more in terms of population. The same trend was noticed in LSgt soils. In LSC, HUF was higher in number than HUB only at week4, there were slight variations in the other weeks. In LSpg; HUB was higher in count in week1, peaked in week 2 and then proceeded to decrease in number. HUF peaked in week 1.However, at week $8 \mathrm{HUF}$ was higher than HUB.TSC peaked at week 4 and became highest in number among the others by week8.THC peaked at week 4, and slightly increased by week8. The peak of the bioremediation was by week2 when HUB count was highest (Fig. 1c and 1d).

In Figure 2, for the RSgt soil samples, HUB was highest in week 1 , peaked again in week
4, before finally reducing, leaving HUF to pick up. The same trend was observed in RSC samples. For RSpg samples, HUB was more until week 6 when it gave way for HUF. As shown in Figure $2 b$ for RSC, the Peak of the bioremediation was in week 4 with HUB, by week 8 fungi took over and the Hydrocarbon utilizers became the lowest in number. Similarly, in RSpg the peak was at week 4 with HUB, when TPH dropped between weeks 6 and 8, fungi took over (Fig. 2c and 2d).

The results for POS samples were shown in Figure 3. In POSC, HUF was highest in week 1 , and then alternated within the weeks. HUB peaked in week 2 , decreased and peaked again in week 8 . The peak was in week 2 with HUB doing more (Fig. 3b). POSpg; the peaks were in weeks 1 and 8 with HUB doing more. Here the pig manure was more of a source of HUB than HUF (Fig. 3c and 3d).

The rates of crude oil biodegradation after manure application as quantified by GC Fig. 4 . The results showed that pig manure was a better remediation-agent than goat manure in the LS series soil (Fig. 4). In eight weeks, there was no significant difference in enhanced bioremediation between pig manure -amended and goat manure-amended soils (Fig. 5). Also, in the case of RS soils; at week 4 pig manure -amended soil $(79.3 \mathrm{mg} / \mathrm{kg}$ TPH) did better than goat manure-amended soil (114.43 TPH), but by the eight week, there was no significant difference between their performances (Fig. 6).

The tropical soil samples were all slightly acidic, low in moisture and they were rich in organic matter as well as minerals (Table 1). The results showed that the rates of hydrocarbon biodegradation were highest in the first four weeks for all the samples except for LSC and POSC, after which they declined in all except in the two mentioned above. This 
finding agreed with that of Obire and Nwaubeta, (2001). Pig manure was a better remediation-agent than goat manure in the LS series soil (Figure 4) since it seemed to harbour certain physicochemical constituents and biological properties that favored bioremediation of LS soils more than goat manure.

In the absence of manures, there was biodegradation, though at a slower rate than in those amended with manures. In the POS series, something out of the trend was observed between week 2 and 4 in the control, the TPH became slightly increased. This may be attributed to experimental bias or to the migration of hydrocarbons from the atmosphere into the soil samples. But for the manure - amended soils, POSpg at week 4 $(69.46 \mathrm{mg} / \mathrm{kg} \mathrm{TPH})$ was better bioremediated than POSgt (147.29 mg/kg TPH).

However, by the eight week, there was no significant difference in enhanced bioremediation between pig manure - amended and goat manure-amended soils (Figure 5). Also, in the case of RS soils, at week 4 pig manure $(79.3 \mathrm{mg} / \mathrm{kg}$ TPH) did better than goat manure (114.43 TPH), but by the eight week, there was no significant difference between their performances (Figure 6). This could mean that in the long run, goat and pig manures were equally good bioremediation-agents, though pig manure does so faster.

In terms of percentage petroleum hydrocarbon loss, a total of $56.44 \%$ loss was seen with LSC, $89.67 \%$ and $80.38 \%$ losses in LSpg and LSgt samples respectively over the eight weeks period. Ijah et al., (2008) recorded a $56.3 \%$ crude oil loss in un-amended polluted tropical soil and a $75 \%$ loss in chicken dropping- amended soil. A total percentage loss of $99.79 \%$ and $99.76 \%$ respectively for the pig manure-amended and goat manureamended RS soils was observed against $61.45 \%$ loss in the un-amended control soil (Table 2-5).

Table.1A Determination of physico-chemical parameters of soils before manure amendment

\begin{tabular}{|c|c|c|c|c|c|c|c|c|}
\hline \multirow[t]{2}{*}{ Soil code } & \multicolumn{8}{|c|}{ Physico-chemical parameters } \\
\hline & $\mathrm{pH}$ & $\begin{array}{l}\text { Moisture } \\
\%\end{array}$ & $\begin{array}{l}\text { TOM } \\
\%\end{array}$ & $\underset{\mathrm{mg} / \mathrm{kg}}{\mathrm{Na}}$ & $\underset{\mathrm{mg} / \mathrm{kg}}{\mathrm{K}}$ & $\underset{\mathrm{mg} / \mathrm{kg}}{\mathrm{NH}_{4} \mathrm{~N}}$ & $\mathrm{NO}_{\mathrm{mg}}^{-3}$ & $\begin{array}{l}\text { Phosphorus } \\
\mathrm{mg} / \mathrm{kg}\end{array}$ \\
\hline $\mathbf{R S}$ & 6.6 & 2.61 & 75.87 & 1.64 & 57.46 & ND & 55.34 & 42.88 \\
\hline $\mathbf{L S}$ & 6.5 & 9.15 & 96.66 & 2.36 & 82.59 & ND & 55.34 & 49.74 \\
\hline OS & 6.8 & 1.64 & 94.12 & 6.81 & 29.10 & ND & 23.85 & 75.07 \\
\hline
\end{tabular}

KEY:RS- River state, LS- Lagos state, OS- Oriade LGA (soil with no previous history of oil contamination) TOM- Total organic matter

Table.1B Physicochemical properties of soils before manure amendment

\begin{tabular}{|l|l|r|r|r|r|l|l|r|r|}
\hline Code & \multicolumn{2}{|c|}{ Parameters } \\
\hline RS & pH & Moisture (\%) & TOM & Sodium & Potassium & NH4-N & Nitrate & Available phosphorus \\
\hline LS & 6.6 & 2.61 & 75.87 & 164.09 & 57.46 & ND & 55.34 & 42.88 \\
\hline OS & 6.5 & 9.15 & 96.66 & 236.11 & 82.59 & ND & 55.34 & 49.74 \\
\hline POS & 5.8 & 1.64 & 94.12 & 681.05 & 29.1 & ND & 23.85 & 75.07 \\
\hline POSC & 6.3 & 9.69 & 82.85 & 336.01 & 52.46 & 6.06 & 25.2 & ND & 43.44 \\
\hline
\end{tabular}


Table.2 Physicochemical properties of manure-amended and Un-amended polluted soils at (week 10)

\begin{tabular}{|l|l|l|l|l|l|l|l|l|}
\hline Sample & $\mathrm{pH}$ & Moisture & $\mathbf{T O M}$ & $\mathbf{N a}$ & $\mathbf{K}$ & $\mathbf{N H}_{4}-\mathrm{N}$ & $\mathbf{N O}^{3-}$ & $\mathbf{P}$ \\
\hline POSC & $6.0 \pm 0.17 \mathrm{a}, \mathrm{b}$ & $0.98 \pm 0.03 \mathrm{c}$ & $4.99 \pm 0.02 \mathrm{c}$ & $367.59 \pm 0.05 \mathrm{c}$ & $9.6 \pm 0.01 \mathrm{~b}$ & $1.9 \pm 0.04 \mathrm{c}$ & $3.9 \pm 0.20 \mathrm{a}$ & $5.62 \pm 0.04 \mathrm{~b}$ \\
\hline POSpg & $5.7 \pm 0.02 \mathrm{~b}$ & $1.45 \pm 0.03 \mathrm{a}$ & $8.70 \pm 0.01 \mathrm{a}$ & $454.91 \pm 0.07 \mathrm{a}$ & $10.15 \pm 0.03 \mathrm{a}$ & $2.2 \pm 0.06 \mathrm{~b}$ & $3.7 \pm 0.05 \mathrm{a}$ & $6.20 \pm 0.04 \mathrm{a}$ \\
\hline POSgt & $6.1 \pm 0.02 \mathrm{a}$ & $1.11 \pm 0.06 \mathrm{~b}$ & $8.00 \pm 0.01 \mathrm{~b}$ & $396.06 \pm 0.07 \mathrm{~b}$ & $8.8 \pm 0.05 \mathrm{c}$ & $2.4 \pm 0.04 \mathrm{a}$ & $2.9 \pm 0.08 \mathrm{~b}$ & $6.17 \pm 0.02 \mathrm{a}$ \\
\hline RSC & $\mathbf{7 . 9} \pm \mathbf{0 . 1 0 a}$ & $\mathbf{1 . 5 0} \pm \mathbf{0 . 0 2 c}$ & $\mathbf{9 . 4} \pm \mathbf{0 . 0 3 c}$ & $\mathbf{4 5 0 . 0 0} \pm \mathbf{0 . 1 4 a}$ & $\mathbf{6 . 5} \pm \mathbf{0 . 0 2 c}$ & $\mathbf{1 . 6} \pm \mathbf{0 . 0 3} \mathbf{b}$ & $\mathbf{4 . 1} \pm \mathbf{0 . 0 3 a}$ & $\mathbf{6 . 7} \pm \mathbf{0 . 0 5 a}$ \\
\hline RSpg & $7.0 \pm 0.5 \mathrm{c}$ & $\mathrm{i} .82 \pm 0.03 \mathrm{~b}$ & $11.53 \pm 0.07 \mathrm{a}$ & $370.22 \pm 0.03 \mathrm{~b}$ & $40.7 \pm 0.05 \mathrm{a}$ & $1.8 \pm 0.07 \mathrm{a}$ & $3.5 \pm 0.12 \mathrm{~b}$ & $6.24 \pm 0.06 \mathrm{~b}$ \\
\hline RSgt & $7.5 \pm 0.10 \mathrm{~b}$ & $6.80 \pm 0.04 \mathrm{a}$ & $9.68 \pm 0.07 \mathrm{~b}$ & $304.65 \pm 0.05 \mathrm{c}$ & $11.9 \pm 0.16 \mathrm{~b}$ & $1.9 \pm 0.04 \mathrm{a}$ & $2.6 \pm 0.03 \mathrm{c}$ & $5.84 \pm 0.08 \mathrm{c}$ \\
\hline LSC & $\mathbf{6 . 7} \pm \mathbf{0 . 3 a}$ & $\mathbf{1 . 9} \pm \mathbf{0 . 1 4 c}$ & $\mathbf{7 . 5} \pm \mathbf{0 . 0 9}$ & $\mathbf{3 9 9 . 2 6} \pm \mathbf{0 . 6 4 b}$ & $\mathbf{4 . 7} \pm \mathbf{0 . 1 1} \mathbf{c}$ & $\mathbf{1 . 1 2} \pm \mathbf{0 . 0 5} \mathbf{b}$ & $\mathbf{2 . 9} \pm \mathbf{0 . 1 1 b}$ & $\mathbf{6 . 3} \pm \mathbf{0 . 0 3 b}$ \\
\hline LSpg & $6.5 \pm 0.1 \mathrm{a}$ & $3.93 \pm 0.04 \mathrm{~b}$ & $20.11 \pm 0.02 \mathrm{~b}$ & $395.85 \pm 0.14 \mathrm{c}$ & $11.7 \pm 0.16 \mathrm{~b}$ & $2.1 \pm 0.13 \mathrm{a}$ & $4.7 \pm 0.05 \mathrm{a}$ & $8.4 \pm 0.08 \mathrm{a}$ \\
\hline LSgt & $6.9 \pm 0.2 \mathrm{a}$ & $5.11 \pm 0.02 \mathrm{a}$ & $22.12 \pm 0.05 \mathrm{a}$ & $454.94 \pm 0.09 \mathrm{a}$ & $34.5 \pm 0.11 \mathrm{a}$ & $1.17 \pm 0.03 \mathrm{~b}$ & $2.2 \pm 0.07 \mathrm{c}$ & $6.06 \pm 0.13 \mathrm{c}$ \\
\hline
\end{tabular}

*values are Means \pm Standard Deviations of triplicate results

Means \pm SD with similar superscripts in the same column are not significantly different from each other at $\mathrm{P}>0.05$ for the different series studied.

** TOM- Total organic matter and Moisture are in \%, others with the exception of $\mathrm{pH}$ are in $\mathrm{mg} / \mathrm{kg}$

Table.3 Physicochemical parameters of manures used

\begin{tabular}{|l|l|l|l|l|}
\hline $\begin{array}{l}\text { Manure } \\
\text { code }\end{array}$ & pH & $\begin{array}{l}\text { Nitrogen } \\
(\%)\end{array}$ & Phosphorus(mg/kg) & Potassium(mg/kg) \\
\hline Gt & $\mathbf{5 . 9} \pm \mathbf{0 . 0 2}$ & $\mathbf{3 . 7 3} \pm \mathbf{0 . 0 9}$ & $\mathbf{2 6 . 7 8} \pm \mathbf{0 . 0 9}$ & $\mathbf{1 2 . 9 0 \pm 0 . 0 9}$ \\
\hline Pg & $\mathbf{5 . 8} \pm \mathbf{0 . 1 1}$ & $\mathbf{2 . 1 4} \pm \mathbf{0 . 0 4}$ & $\mathbf{1 2 . 9 8} \pm \mathbf{0 . 0 9}$ & $\mathbf{1 4 . 7 0} \pm \mathbf{0 . 0 3}$ \\
\hline
\end{tabular}

$*$ Values are means \pm Standard deviations of duplicate results; 'pg' represents pig manure, while 'gt' represents goat manure

Table.4 Maize growth characteristics at 10 DAP (biomass 16 DAP) at week 10 of manure application on unpolluted, polluted and amended soils

\begin{tabular}{|c|c|c|c|c|c|}
\hline Sample & stem length & leaf height & biomass & germination rate & $\begin{array}{l}\text { no of days to } \\
\text { germination }\end{array}$ \\
\hline OS & $5.10 \pm 0.53 b$ & $19.53 \pm 1.74 a$ & $1.45 \pm 0.0 \mathrm{~b}$ & 3 & ( \\
\hline POSC & $3.55 \pm 0.58 \mathrm{c}$ & $12.60 \pm 0.60 \mathrm{~b}$ & $0.27 \pm 0.10 \mathrm{c}$ & 2 & 3 \\
\hline POSpg & $6.20 \pm 0.47 a$ & $21.50 \pm 1.05 \mathrm{a}$ & $2.41 \pm 0.10 \mathrm{a}$ & 2 & 3 \\
\hline POSgt & $5.50 \pm 0.96 a, b$ & $21.50 \pm 3.65 a$ & $1.64 \pm 0.17 b$ & 1 & 3 \\
\hline RSC & 0 & 0 & 0 & 2 & 16 \\
\hline RSpg & $3.00 \pm 1.0 \mathrm{a}$ & $10.05 \pm 3.55 \mathrm{a}$ & $1.37 \pm 0.18 b$ & 1 & 5 \\
\hline RSgt & $1.70 \pm 0.10 b$ & $3.6 \pm 0.10 \mathrm{~b}$ & $1.76 \pm 0.37 \mathrm{a}$ & 1 & 6 \\
\hline LSC & 0 & 0 & $0.34 \pm 0.33 b$ & 2 & 16 \\
\hline LSpg & $4.46 \pm 0.15 a$ & $20.36 \pm 0.75 a$ & $1.97 \pm 0.42 \mathrm{a}$ & 2 & 4 \\
\hline LSgt & $4.50 \pm 0.3 \mathrm{a}$ & $18.00 \pm 0.10 \mathrm{a}$ & $2.03 \pm 0.56 a$ & 1 & 3 \\
\hline
\end{tabular}

*Means \pm SD of values with similar superscripts in the same column are not significantly different at $\mathrm{P}>0.05$ for the OS, POSC series together, RS series and for the LS series differently 
Table.5 Biochemical and morphological characterization of bacterial isolates

\begin{tabular}{|c|c|c|c|c|c|c|c|c|c|c|c|c|c|c|c|c|c|c|c|c|c|c|c|c|c|c|c|}
\hline $\begin{array}{l}\frac{0}{0} \\
8 \\
0 \\
\frac{0}{\pi} \\
\frac{0}{0} \\
0 \\
0\end{array}$ & 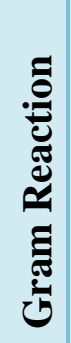 & 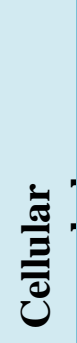 & 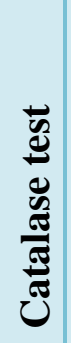 & 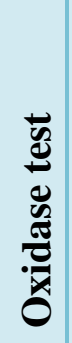 & 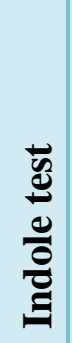 & 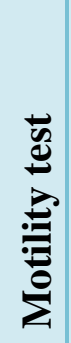 & 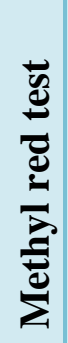 & 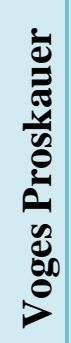 & 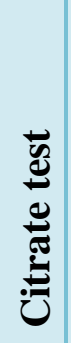 & 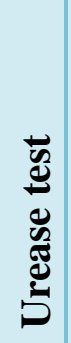 & 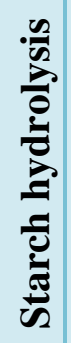 & 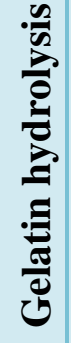 & 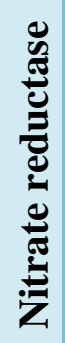 & 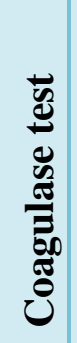 & 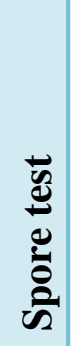 & $\frac{\mathscr{ஜ}}{\circlearrowright}$ & $\frac{\ddot{\theta}}{\vec{x}}$ & 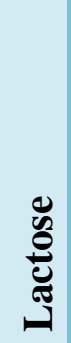 & 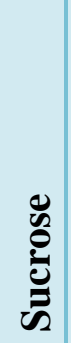 & 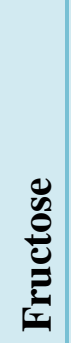 & 幽 & 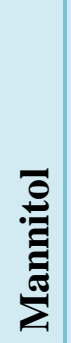 & 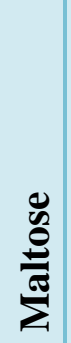 & 总 & 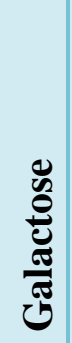 & 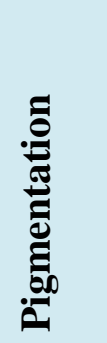 & 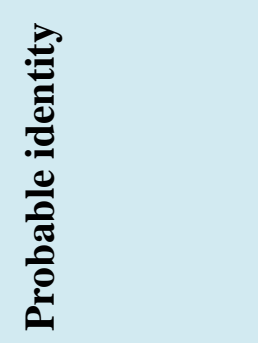 \\
\hline RS1 & + & $\mathrm{R}$ & + & + & - & + & - & + & - & - & + & - & + & - & + & + & + & + & + & - & + & - & + & - & - & $\begin{array}{l}\text { Crea } \\
\mathrm{m}\end{array}$ & $\begin{array}{l}\text { Bacillus } \\
\text { coagulans }\end{array}$ \\
\hline RS3 & + & $\begin{array}{l}\mathrm{C} / \\
\mathrm{R}\end{array}$ & + & - & - & - & - & + & - & + & + & - & + & - & - & + & - & - & - & - & - & - & + & - & - & $\begin{array}{l}\text { Yell } \\
\text { ow }\end{array}$ & $\begin{array}{l}\text { Corynebacteri } \\
\text { um sp. }\end{array}$ \\
\hline LS3 & + & $\mathrm{C}$ & + & + & - & - & - & - & + & - & - & - & - & - & - & + & + & - & + & - & - & - & + & + & + & $\begin{array}{l}\text { Yell } \\
\text { ow }\end{array}$ & $\begin{array}{l}\text { Micrococcus } \\
\text { varians }\end{array}$ \\
\hline LS4 & - & $\mathrm{R}$ & + & - & - & - & - & - & + & - & - & - & + & - & - & + & - & - & - & - & - & + & - & - & - & $\begin{array}{l}\text { Crea } \\
\mathrm{m}\end{array}$ & $\begin{array}{l}\text { Acinetobacter } \\
\text { mallei }\end{array}$ \\
\hline $\begin{array}{l}\text { PO } \\
\text { S3 }\end{array}$ & + & $\mathrm{R}$ & + & + & - & + & - & + & + & - & + & + & - & - & + & + & + & + & + & + & + & + & + & + & + & $\begin{array}{l}\text { Crea } \\
\mathrm{m}\end{array}$ & $\begin{array}{l}\text { Bacillus } \\
\text { polymyxa }\end{array}$ \\
\hline $\begin{array}{l}\text { PO } \\
\text { S2 }\end{array}$ & + & $\mathrm{R}$ & + & + & - & + & - & - & + & - & + & + & - & - & + & + & + & - & + & - & - & + & - & + & - & $\begin{array}{l}\text { Crea } \\
\mathrm{m}\end{array}$ & $\begin{array}{l}\text { Bacillis } \\
\text { megaterium }\end{array}$ \\
\hline $\begin{array}{l}\text { PG } \\
1\end{array}$ & + & $\mathrm{C}$ & + & + & - & + & - & - & - & - & - & - & - & - & - & + & + & - & - & - & - & + & + & - & - & Pink & $\begin{array}{l}\text { Micrcoccusro } \\
\text { seus }\end{array}$ \\
\hline $\begin{array}{l}\text { GT } \\
1\end{array}$ & + & $\mathrm{R}$ & + & + & - & + & - & + & + & - & + & + & + & - & + & + & - & + & + & - & - & + & - & + & + & $\begin{array}{l}\text { Crea } \\
\mathrm{m}\end{array}$ & $\begin{array}{l}\text { Bacillus } \\
\text { subtilis }\end{array}$ \\
\hline
\end{tabular}




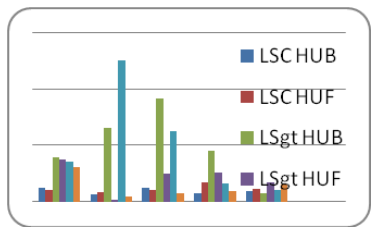

Fig 1a: Counts of Petroleum Utilizing bacteria and fungi after manure application in LS

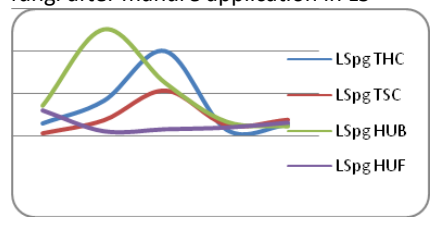

Fig 1c: Total microbial count after manure application in LSpg

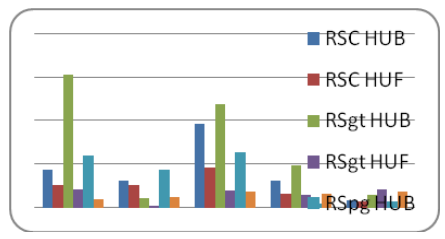

Fig 2a: Counts of Petroleum Utilizing bacteria and fungi after manure application in RS

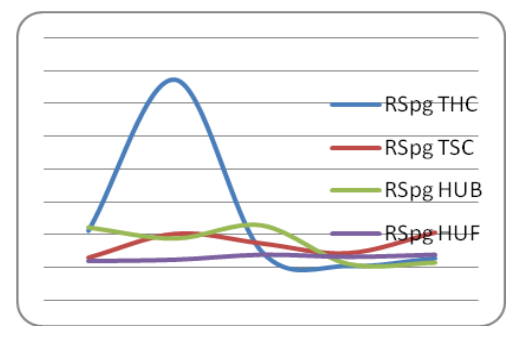

Fig. 2c: Total microbial count after manure application in RSpg

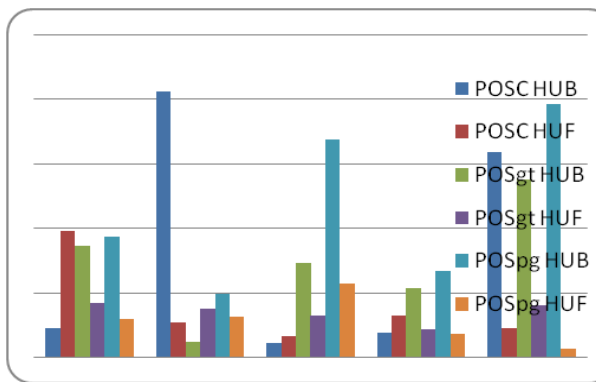

Fig.3a: Counts of Petroleum Utilizing bacteria and fungi after manure application in POS

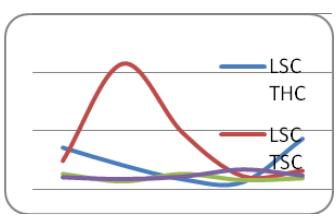

Fig1b: Total microbial counts in LSC over the eight weeks experimental period.

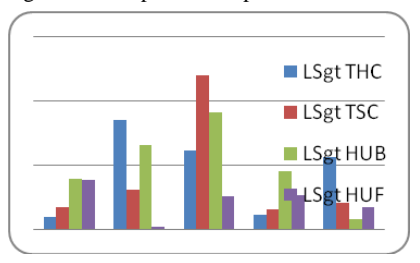

Fig 1d: Total microbial count after manure application in

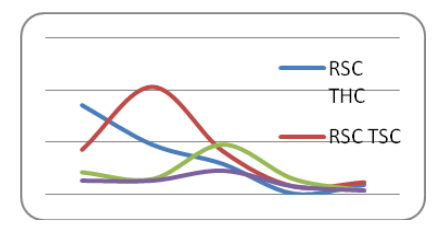

Fig.2b: Total microbial count over the eight weeks experimental period in RSC

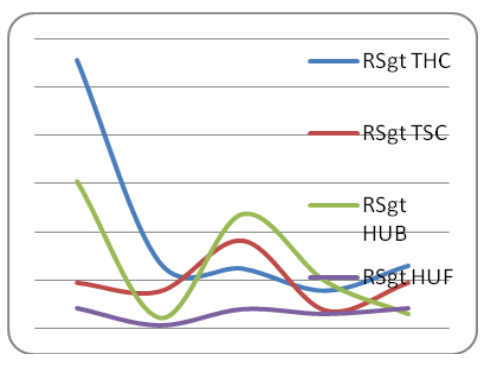

Fig. 2d: Total microbial count after manure application in RSgt

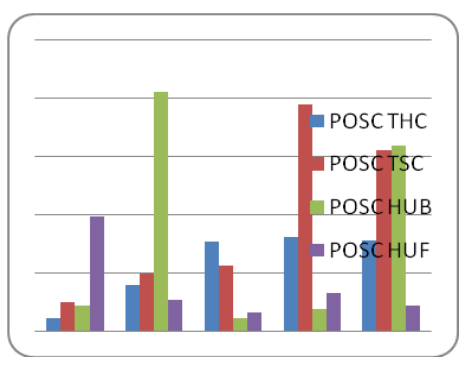

Fig. 3b: Total microbial counts over the eight weeks experimental period in POSC

** POSC is the code for the control sample of the $P O S$ soils without manure amendment, any code having ' $p g^{\prime}$ ' have been amended with pig manure, any with 'gt' have been amended with goat manure. 


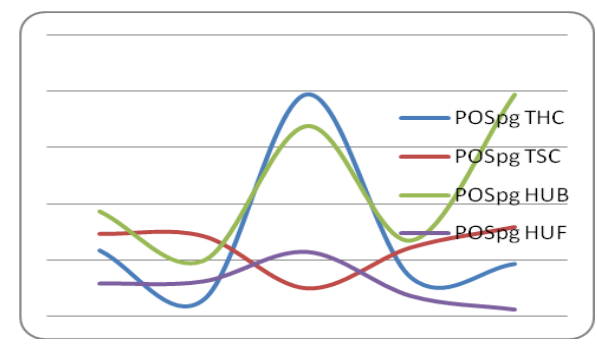

Fig.3c: Total microbial count after manure application in POSpg
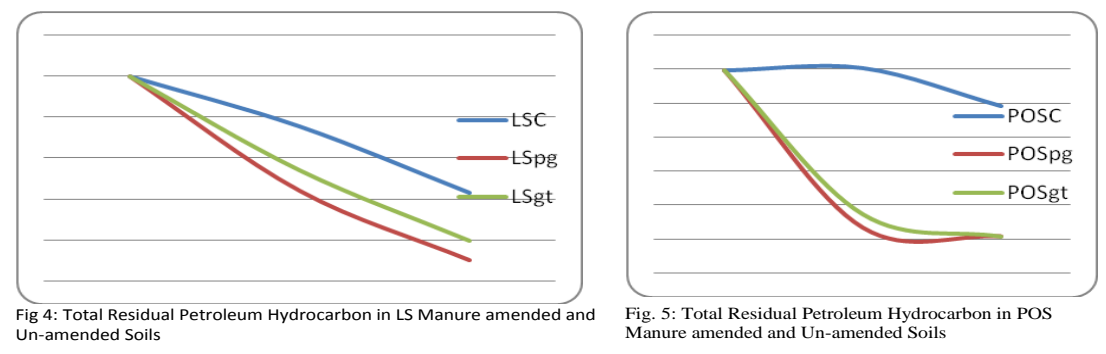

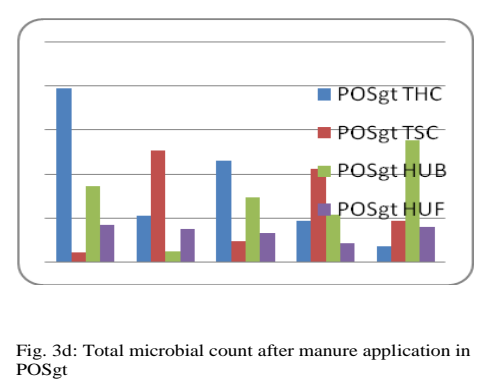

rocarbon in POS Manure amended and Un-amended Soils

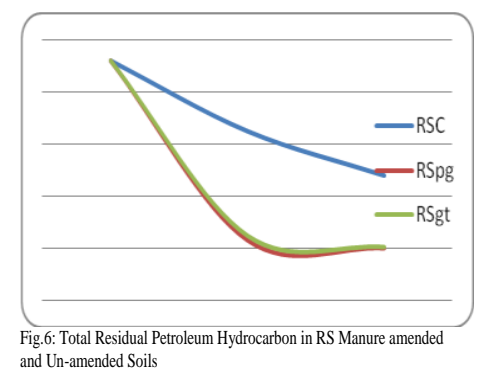

Similar results were obtained for the pig manure-amended and goat manure-amended POS soil samples except for the un-amended polluted control that registered only a $21.14 \%$ loss in total petroleum hydrocarbon. This may be attributed to the soil type and its characteristics that reduced the onset of biodegradation.

\section{Effect of Manure Amendment on soil physicochemical parameters}

The effect of manure amendment on soil physicochemical properties; Apart from potassium, goat manure is higher than pig manure in all the other parameters studied. In RS samples, $\mathrm{pH}$ increase was higher in the control RSC than in the RSgt and RSpg- this showed that the pig manure was better in maintaining the $\mathrm{pH}$ range for optimal bioremediation in the soil studied; moisture increased in RSgt than in the other two; supported the growth of both petroleum hydrocarbon utilizers and non-users. This is in line with the findings of Okolo et al., (2005). HUB alternated in number between the weeks and stabilized in the last 2 weeks. A similar trend was seen in HUF. The peak of the work seemed to be in week 6 with HUF doing more (Fig. 1b). It might mean that the heterotrophs and saprophytes generated certain metabolites that in some weeks reduced the number of the petroleum hydrocarbon users, until week 6 when the condition favoured the growth of HUF which completed the biodegradation process. Hence, future research would have to 
both detect and evaluate the presence of some of these metabolites limiting the onset of biodegradation in a mixed population.

In LSpg; the first two weeks HUB and HUF were actively biodegrading but by week 8 , when the ТPH had drastically reduced, the saprophytic fungi had more or less taken over the soil. This suggested that petroleumpolluted soils generally support the growth of organisms which use the petroleum components as sources of carbon and energy (Atlas, 1977; Leahy and Colwell, 1990). LSgt; The results showed that the hydrocarbon users began equally well by the first week, with the HUB being more at the biodegradation until the final week when the HUF took over. The peak of the bioremediation was at week 6 when the $\mathrm{HC}$ users were more than the total count of both bacteria and fungi (Fig. 1d). Total organic matter and sodium decreased in all, but was lowest in the control and highest in POSpg; potassium slightly increased in all except POSgt. In $\mathrm{RS}$ samples, $\mathrm{pH}$ increase was higher in the control RSC than in the RSgt and RSpg- this showed that the pig manure was better in maintaining the range of $\mathrm{pH}$ for optimal bioremediation in the soil studied; moisture increased in RSgt than in the other two; total organic matter decreased but more in RSC, least in RSpg, this showed that the manures added organic matter to the soil; sodium increased but more in RSC, least in RSgt, this might suggest that some organisms in the manures were making use of the sodium for their cellular activities; potassium decreased but most in RSC, least in RSpg; ammonium increased but most in RSpg and RSgt; nitrate decreased most in RSgt, least in RSC; phosphorus decreased most in RSgt, least in RSC.

In LS samples, there was no significant change in $\mathrm{pH}$ between the three. These results showed that apart from improved soil fertility brought about by the addition of these organic nutrients to soil, the addition of goat dung and pig droppings to oil-polluted soils will result in an increase in the population of total saprophytic fungi, total heterotrophic bacteria and an increase in the population of petroleum-utilizing microorganisms in soil.

In conclusion the organic manure is an excellent bio-stimulant that enhances the performance of native hydrocarbonclastic bacteria provided the physicochemical parameters are optimum in a tropical environment and it is environment-friendly.

\section{References}

Adebusoye, S. A., Ilori, M. O., Amund, O. O., Teniola, O. D. and Olatope, S. O. (2007). Microbial degradation of petroleum hydrocarbons in a polluted tropical stream. World Journal of Microbiology and Biotechnology 23: 1149- 1159.

Adedokun O.M., and Ataga, A.E. (2007). Effects of amendments and bioaugmentation of soil polluted with crude oil, automotive gasoline oil, and spent engine oil on the growth of cowpea (Vigna unguiculata L. Walp). Scientific Research and Essay2(5):147-149.

Agarry, S. E.Aremu, M. O. and Aworanti, O. A.(2013) Kinetic Modelling and Half-Life Study on Enhanced Soil Bioremediation of Bonny Light Crude Oil Amended with Crop and Animal-Derived Organic Wastes, Journal of Petroleum \& Environmental Biotechnology 4:2 http://dx.doi.org/10.4172/21577463.1000137

Amadi, A., and Uebari,Y. (1992). Use of poultry manure for amendment of oil polluted soils in relation to growth of maize (Zea mays L). Environment International18:521-527.

Amadi A., Dickson, A. A. and Maate, G.O. (1993). Remediation of oil - polluted soils; Effect of organic and inorganic nutrient supplements on the performance 
of maize (Zea mays L). Water, Air and Soil Pollution66:59-76.

Atlas, R. M. (1981).Microbial degradation of petroleum hydrocarbons: An environment perspective. Microbiological Reviews45:180-208.

Baker, K. H. and Herson, D. (1994). Microbiology and biodegradation. In: Bioremediation (eds.) Baker K. \& Herson D. McGraw Hill Inc., New York, Pp. 9 60.

Bauchop, T., Elsden, S.R. (1960). The growth of microorganisms in relation to their energy. Journal of General Microbiology23:457- 459.

Carmichael, L. M., and Pfaender, F.K. (1997). The effect of inorganic and organic supplements on the microbial degradation of phenanthrene and pyrene in soils. Biodegradation8: 1-13.

Datta, R., Meena, R., Pathan, S., and Ceccherini, M. (2019). Biochar and Organic Amendments for Sustainable Soil Carbon and Soil Health. In: Carbon and Nitrogen Cycling in Soil. Earth and Environmental Science Springer, Singapore DOI, https://doi.org/10.1007/978-981-13-72643-3,

Doran, J.W., and Parkin, T. B. (1994). Defining and Assessing Soil Quality. In: Defining Soil Quality for a Sustainable Environment. Soil Science Society of America special publication 35: 3 - 21.

Ezeji, E.U., Anyanwu, B. N. Onyeze, G.O.C., and Ibekwe V.I. (2005). Studies on the utilization of petroleum hydrocarbons by microorganisms isolated from oil polluted soil. International Journal of Natural and Applied Sciences.1(2):122-128.

Ezeji, U.E., Anyadoh, S. O. and Ibekwe, V.I. (2007): Clean up of crude oilcontaminated soil. Terrestrial and aquatic Environmental Toxicology 1(2): 54-59.

Global Science Books. Ibekwe, V.I.K., Ubochi, C. and Ezeji, E.U., (2005). Effect of organic nutrient on microbial utilization of hydrocarbons on crude oil contaminated soil. African Journal of
Biotechnology5 (10):983 - 986.

Ijah, U. J. J., Safiyahu, H., and Abioye, O. P. (2008). Comparative Study of Biodegradation of Crude Oil amended with Chicken. Droppings and NPK Fertilizer. Science World Journal, 3(2):63 $-67$.

Kastner, M., Breuer-Jammali, M., andMahro, B. (1994). Enumeration and characterization of the soil microflora from hydrocarboncontaminated soil sites able to mineralize polycyclic aromatic hydrocarbons. Applied Microbiology and Biotechnology, 41: $264-273$.

Leahy, J. G., and Colwell, R. R. (1990). Microbial Degradation of Hydrocarbons in the Environment. Microbiological Reviews5(3):305-315.

Malloch, D. (1997). Moulds Isolation, Cultivation and Identification, Department of Botany, University of Toronto, Toronto USA.

Moyin-Jesu, E. I. (2019). Comparative Evaluation of Different Organic Fertilizers on The Soil Chemical Composition, Growth, Leaf and Fruit Yields of Fluted Pumpkin (Telfaria occidentalis L.): American Journal of Research Communication, 7(3).

Nwogu, T. P., Azubuike, C.C. and Ogugbue, C. J. (2015). Enhanced Bioremediation of Soil Artificially Contaminated with Petroleum Hydrocarbons after Amendment with Capra aegagrushircus (Goat) Manure, Hindawi Publishing Corporation Biotechnology Research International Article ID 657349, 7p. http://dx.doi.org/10.1155/2015/657349.

Obire, O., and Nwaubeta, O. (2001). Biodegradation of Refined Petroleum Hydrocarbons in Soil. Journal of Applied Sciences and Environmental Management. 5 (1):43 - 46.

Obire, O., Anyanwu, E. C. and Okigbo, R.N. (2008). Saprophytic and crude oil degrading fungi from cow dung and poultry droppings as bioremediating agents. Journal of Agricultural Technology4 (2): 81 - 89. 
Obire, O, and Akinde, S.B. (2006). Comparative study of the efficiency of cow dung and poultry manure as nutrient alternative sources in bioremediation of oil polluted soil. Niger Delta Biologia 5(2): 82 - 91.

Okoh, A. I. (2006). Biodegradation alternative in the clean-up of petroleum hydrocarbon pollutants. Biotechnology and Molecular Biology Review1 (2): 38 - 50.

Okolo, J. C., Amadi, E. N. and Odu, C. T. I. (2005).Effects of soil treatments containing poultry manure on crude oil degradation in a sandy loamy soil. Applied Ecology and Environmental Research3(1): 47-53.

Onuh, M.O., Ohazurike, N. C. and Madukwe, D. K. (2008). Interaction of Crude Oil and Manure Treatments and Its Effects on the Agronomic Characteristics of Maize (Zea mays L.) Science World Journal3 (2):107 - 111.

Onwurah, I. N. E., Ogugua, V. N., Onyike, N. B., Ochonogor, A. E., and Otitoju, O. F. (2007).

Crude oil spills in the Environment, Effects and Some Innovative Clean-up Biotechnologies. International journal of Environmental Research. 1(4):307320.

Owabor, C. N. and Yusuf, R. O. (2010). Bioremediation of Soil Artificially
Contaminated with

Petroleum Hydrocarbon Oil Mixtures: Evaluation of the Use of Animal Manure and Chemical Fertilizer, (Ed. S. E. Agarry), P. 189-195 | Published online: 06 Nov 2010, https://doi.org/10.1080/10889868.2010.51 4965.

Raymond, R. L., Hudson, J. O. and Jamison, V. W. (1976). Oil degradation in soil. Applied and Environmental Microbiology31: 522-535.

Sabate, J., Vinas, M., and Solanas, A. M. (2004). Laboratory-scale bioremediation experiments on hydrocarbon Contaminated soils. International journal of Biodeterioration and Biodegradation 54: 19-25.

Verma, M. L., Saini, R., Sharma S., Rani V., Jana A. K. (2020) Suitability of the Lantana Weed as a Substrate for Biogas Production. In: Srivastava N., Srivastava M., Mishra P., Gupta V. (eds) Substrate Analysis for Effective Biofuels Production. Clean Energy Production Technologies. Earth and Environmental Science Springer, Singapore DOI https://doi.org/10.1007/978-981-32-96077_3, Print ISBN 978-981-32-9606-0

\section{How to cite this article:}

Ojo-Omoniyi, O. A., N. Dike-Ekeh and Owoeye, O. M. 2020. A Comparative Study of Enhanced Crude Oil Degradation in Three Tropical Soils using Pig and Goat Manures as Organic Amendments. Int.J.Curr.Microbiol.App.Sci. 9(08): 2317-2329. doi: https://doi.org/10.20546/ijcmas.2020.908.266 